\title{
The United Nations Working Group on the Issue of Discrimination against Women in Law and Practice
}

\author{
FAREDA BANDA
}

\section{Introduction}

In 1995, at the Fourth World Conference on Women in Beijing, governments undertook to 'revoke any remaining laws that discriminate on the basis of sex'. ${ }^{1}$ This chapter looks at how the failure by states to meet that challenge led to the decision by the Human Rights Council in 2010 to appoint a United Nations Working Group on Laws that Discriminate against Women (hereafter WG). It retraces the steps that led to the appointment of the group, including the important input of non-governmental organizations (NGOs) whose persistence drove the process along. ${ }^{2}$ I also consider my own involvement as a consultant hired by the Women and Gender Unit of the Office for the High Commissioner for Human Rights (OHCHR) to conduct a study on the desirability or otherwise of having a special mechanism within the Special Procedures Framework ${ }^{3}$ to address

My thanks to Anne Hellum for her helpful insights. Thanks are also due to the anonymous reviewer(s).

${ }^{1}$ Beijing Declaration and Platform for Action 1995, A/CONF.177/20/Rev.1 [hereinafter the Beijing Declaration].

${ }^{2}$ Equality Now was the organization that initiated discussions on the failure of states to meet the Beijing goals and that, working in coalition with other NGOs, acted as the lead advocate for the Special Rapporteur project. Equality Now, 'NGO coalition in support of the creation of a Special Rapporteur on Laws that Discriminate against Women', available at: www.equalitynow.org/sites/default/files/annualreport_2005.pdf (last accessed 14 February 2013); J. Neuwirth, 'Inequality before the law: holding states accountable for sex discriminatory laws under the Convention on the Elimination of All Forms of Discrimination against Women through the Beijing Platform for Action', Harvard Human Rights Journal 18 (2005) 19-54, at 20.

${ }^{3}$ Special Procedure mechanisms that fall under the auspices of the High Commission for Human Rights generally fall into two categories - country situation or thematic studies. 
discriminatory laws. ${ }^{4}$ The chapter then considers the mandate of the WG and identifies challenges and opportunities for the work of the group.

The chapter observes the interaction between international NGO's, different UN bodies such as the Human Rights Council, the Commission on the Status of Women (CSW), the Committee on the Elimination of All Forms of Discrimination against Women (CEDAW Committee) and different states. In doing so, the chapter provides a window into the multiple negotiations and power struggles that take place within the UN system: power struggles between (1) NGO's setting out to strengthen women's protection against discrimination and UN bodies; (2) power struggles within and between different UN bodies competing for scarce resources; and (3) power relations between States Parties and UN bodies in the context of a political climate with intensifying conflicts.

\section{History}

The Beijing pledge to eliminate discriminatory laws seemed simple and straightforward, requiring states to:

Review national laws, including customary laws and legal practices in the areas of family, civil, penal, labour and commercial law in order to ensure the implementation of the principles and procedures of all relevant international human rights instruments by means of national legislation, and revoke any remaining laws that discriminate on the basis of sex and remove gender bias in the administration of justice. ${ }^{5}$

The principle of non-discrimination, including on grounds of sex, is at the heart of human rights law and embedded in international customary

It is the latter that was envisaged and discussed in this chapter. Thematic mandates have four functions: the preparation of reports on issues pertaining to their area of expertise, visiting states to investigate issues arising, receiving individual complaints from victims of human rights violations within their area, and finally offering support to the Office of the United Nations High Commissioner for Human Rights (OHCHR) in promoting and protecting human rights. ECOSOC, Commission on the Status of Women: Advisability of the Appointment of a Special Rapporteur on Laws that Discriminate against Women, 13 December 2005, UN Doc. E/CN.6/2006/8, paras. 23 and 24 [hereinafter CSW Advisability Report 2005].

${ }^{4}$ F. Banda, Mechanism for Addressing Laws that Discriminate against Women (Geneva: United Nations OHCHR publication, 6 March 2008) [hereinafter the Banda Report], available at:www.ohchr.org/Documents/Publications/laws_that_discriminate_against_ women.pdf (last accessed 24 January 2013).

${ }^{5}$ Beijing Declaration, para. 232(d). 
law. ${ }^{6}$ Despite this, by the time of the 2000 Beijing +5 General Assembly Special Review of the conference, little progress had been made. In the year preceding the review, Equality Now, a US-based NGO, had issued a report that highlighted discrimination in forty-five countries. By the time of the +5 Review in 2000 , only three of the states had moved to change their laws. ${ }^{7}$

At the Beijing +5 Review, states acknowledged the persistence of discrimination, including in law. They agreed that discriminatory laws created a barrier to the realization of the Platform for Action, hence the call to:

Create and maintain a non-discriminatory and gender-sensitive legal environment by reviewing legislation with a view to striving to remove discriminatory provisions as soon as possible, preferably by 2005 , and eliminating legislative gaps that leave women and girls without protection of their rights and without effective recourse against gender-based discrimination. ${ }^{8}$

${ }^{6}$ UN General Assembly, Universal Declaration of Human Rights, 10 December 1948, 217 A (III), available at: www.unhcr.org/refworld/docid/3ae6b3712c.html (last accessed 23 June 2012), Articles 2, 7.

The International Covenant on Civil and Political Rights, 1966 (ICCPR), 999 UNTS 171, entered into force 23 March 1976, Articles 2, 3 and 26; The International Covenant on Economic, Social and Cultural Rights, 1966 (ICESCR), 993 UNTS 3, entered into force 3 January 1976, Articles 2 and 3; Convention on the Rights of the Child, 1577 UNTS 3, entered into force 2 September 1990, Article 2; International Convention on the Protection of all Migrant Workers and Members of their Families, 2220 UNTS 3, entered into force 1 July 2003, Article 7. Convention on the Rights of Persons with Disabilities, 2515 UNTS 3, entered into force 3 May 2008, preamble paras. a, h and p, and Articles 2, 3(b) and (g), 5 and 6. See also CEDAW General Recommendation No. 25, UN Doc., E/ CN.6/2004/CRP.3, Annex 1. Available at: www.un.org/womenwatch/daw/cedaw/recommendations/General\%20recommendation\%2025\%20\%28English\%29.pdf (last accessed 23 June 2012).

CCPR General Comment 18, 10 November 1989, UN Doc. HRI/GEN/1/Rev.6 at 146 (2003); CCPR General Comment 28, 29 March 2000, UN Doc. CCPR/C/21/Rev.1/ Add.10.

CESCR, General Comment No. 16, 11 August 2005, UN Doc. E/C.12/2005/4, para. 16; CESCR General Comment No. 20 on Non-discrimination, 2 July 2009, UN Doc. E/C.12/ GC/20; see also Legal Status and Rights of Undocumented Workers, Inter-American Court of Human Rights, Advisory Opinion, OC-18/03, 17 September 2003, Inter-Am. Ct HR, (Ser. A) No. 18, 2003, paras. 82-110.

${ }^{7}$ Equality Now, 'Words and deeds: holding governments accountable in the Beijing +5 Review process', Women's Action 16:4, 1 July 2000.

8 UNGA, Further Actions and Initiatives to Implement the Beijing Declaration and Platform for Action, 16 November 2000, UN Doc. Assembly Res. S-23/3, para. 68(b). See also para. 68(f). Available at: www.un.org/womenwatch/daw/followup/ress233e.pdf (last accessed 24 January 2013). 
States were also encouraged to ratify the Convention on the Elimination of All Forms of Discrimination against Women (CEDAW) and to limit reservations that undermined the Convention's object and purpose. ${ }^{9}$ The Beijing +5 Outcome document also highlighted the importance of introducing legislation to tackle violence against women including marital rape and laws to eradicate harmful practices including female genital mutilation. ${ }^{10}$

Following the 2000 Review, civil society and academics kept up the pressure, highlighting the continued discrimination against women and urging action. ${ }^{11}$ Equality Now filed three communications under the little-used complaints mechanism of the Commission on the Status of Women (CSW). The first communication, in 2004, identified a selection of forty states chosen for 'geographical and subject matter diversity' to highlight the problem. Only three of the forty states amended their laws. In 2005 Equality Now filed another communication identifying thirty-six remaining recalcitrant states. ${ }^{12}$ The final communication made by Equality Now singled out Saudi Arabia for multiple breaches including a recently enacted law that allowed men to vote in municipal elections but not women. ${ }^{13}$ While the CSW found that the communications had indeed 'revealed a consistent pattern of reliably attested injustice and discriminatory practices against women', it did not make any recommendations for action..$^{14}$ Noting that only fourteen of the forty states originally identified had responded to the communication, Equality Now urged the Commission to continue to pursue states, reminding them of their international law obligations to guarantee equality. ${ }^{15}$ While acknowledging the

9 Ibid. at para. 68.

10 Ibid. at para. 69.

11 C. Meillon and C. Bunch (eds.), Holding on to the Promise: Women's Human Rights and the Beijing +5 Review (New Jersey: Centre for Women's Global Leadership, 2001); Equality Now, 'Words and deeds: holding governments accountable in the Beijing +10 Review process', Women's Action 16.5, Update March 2004; Equality Now, 'Words and deeds: holding governments accountable in the Beijing +10 Review process', Women's Action 16.9, Update February 2007; Equality Now, 'Words and deeds: holding governments accountable in the Beijing +15 Review process', Update: Women's Action 16.10, February 2010; Equality Now, 'Words and deeds: holding governments accountable in the Beijing +15 Review process', Women's Action 16.11, 24 August 2010.

12 Letter from Equality Now (C. Mackinnon and J. Neuwirth) to the Commission on the Status of Women (CSW) on A Communication on the Status of Women, 19 August 2004

13 Letter from Equality Now (J. Neuwirth) to the CSW on Denial of Women's Suffrage in Saudi Arabia, 31 August 2005 (on file with the author).

14 Ibid. at 2.

15 Ibid. at 3. See also CSW Advisability Report 2005, para. 36. 
limited scope of the CSW's mandate, whose primary aim is 'to identify global trends and patterns concerning women's rights, but not to afford direct redress to victims of human rights violations ${ }^{\prime}{ }^{16}$ Equality Now criticised the CSW for not taking a more robust approach to the communications that had pinpointed the existence of a plethora of laws that discriminated against women. Specifically, the CSW was challenged on its failure to make concrete proposals for remedying the problem. ${ }^{17}$ Equality Now pressed for the appointment of a Special Rapporteur who would report annually to the CSW and whose role would include ongoing dialogue with governments as well as highlighting and sharing examples of good practice. Equality Now argued: 'A special rapporteur could address these issues on a thematic basis, cross-cutting national boundaries in a way that CEDAW is not able to do. ${ }^{18}$ The NGO pressure for the creation of a Special Rapporteur continued to build with more than 300 of the participants from 42 countries in the Economic Commission for Europe, which took part in the European Beijing +10 NGO Forum preparatory to the main government meeting, agreeing by consensus, to the creation of a Special Rapporteur on national laws and practices that discriminate against women. ${ }^{19}$

In the interim, in 2004 the CEDAW Committee marked the 25th anniversary of the adoption of the Convention by issuing a statement in which it noted the failure to achieve universal ratification of the Convention as recommended by the Beijing +5 Review. The Committee further noted that while there had been progress in the realisation of women's human rights, still:

It must, however, also be pointed out that in no country in the world has women's full de jure and de facto equality been achieved. Discriminatory laws are still on the statute books of many States parties. The co-existence of multiple legal systems, with customary and religious laws governing personal status and private life and prevailing over positive law and even constitutional provisions of equality, remains a source of great concern. ${ }^{20}$

${ }^{16} \mathrm{OHCHR}$, 'Human Rights Treaty Bodies - Petitions', available at: www2.ohchr.org/english/bodies/petitions/CSW.htm\#women (last accessed 13 February 2012).

17 Equality Now, 'Annual Report 2005: Take a stand, make a difference' at 7.

${ }^{18} \mathrm{Ibid}$. at 4.

19 Equality Now, 'Campaign for a Special Rapporteur on Laws that Discriminate against Women (Beijing +10)', 2004 at 4.

${ }^{20}$ UN Statement to commemorate the twenty-fifth anniversary of the adoption of the Convention on the Elimination of All Forms of Discrimination against Women, 13 October 2004, available at: www.un.org/womenwatch/daw/cedaw/anniversary25.htm (last accessed 9 June 2012). 
The statement also addressed the negative impact of gender stereotyping on women, and their limited access to power and decision-making as well as resources. The Committee addressed the lack of political will to bring about gender equality as a key problem. ${ }^{21}$

The following year (2005), to mark Beijing +10 , the CEDAW Committee issued a statement in which it acknowledged the 'synergies' between the Beijing Platform for Action and the CEDAW and noted that the two complemented each other with the Platform drawing attention to women's rights and the Convention acting as the 'primary instrument for the promotion of equality between women and men and the elimination of all forms of discrimination against women'. ${ }^{22}$

At its 49th session in 2005, the CSW, the body tasked with keeping conference pledges under review (in this case Beijing +10 ), identified the continuation of both de jure and de facto discrimination and, shockingly, that rather than eliminating discriminatory laws, some states had actually introduced them. In a resolution the CSW asked the OHCHR to advise on the implications of appointing a Special Rapporteur on laws that discriminate against women, paying attention to avoiding duplication with existing mandates. ${ }^{23}$ At the invitation of the CSW, the OHCHR consulted the CEDAW Committee about its views on the need for a new mechanism. ${ }^{24}$ Not surprisingly the CEDAW Committee did not 'see the necessity' for establishing the mandate because its remit was to tackle discrimination against women in both law and practice. However, the Committee did go on to make proposals for the form that any mandate should take in the event that the Commission decided to proceed. ${ }^{25}$ These included a

21 Ibid.

22 UN Report of the Committee on the Elimination of Discrimination against Women, 32nd Session, Statement of the Committee on the Elimination of Discrimination against Women on the Occasion of the 10 Year Review and Appraisal of the Beijing Declaration and Platform for Action (General Assembly Official Records, 60th session, Supplement No. $38(\mathrm{~A} / 60 / 38)$.

23 Commission on the Status of Women, Final Report of the 49th Session of the CSW, Resolution 49/3 on the Advisability of the Appointment of a Special Rapporteur on Laws that Discriminate against Women, E/CN.6/2005/11. See also Equality Now, 'Statement in support of a Special Rapporteur on Laws that Discriminate against Women', August 2005.

24 It is interesting to note that the while supportive of CSW Resolution 49, the United States objected to the suggestion that the CEDAW Committee be consulted about the creation of a Special Rapporteur, noting that it was inappropriate as: 'that is beyond the mandate of that Committee'. US Statement: Special Rapporteur on Laws that Discriminate against Women, 49th Session, UN CSW, available at: http://2001-2009.state.gov/p/io/ uncnf/43762.htm (last accessed June 2012).

25 CSW Advisability Report 2005, para. 40. 
focus on: a requirement to address various types of discriminatory laws; customary and other forms of law (common and codified law); and de jure and de facto discrimination against women. The mandate should clearly spell out the scope of the discriminatory legislation to be covered and should also include indirect discrimination. Lastly, the Commission should consider the ways in which a mandate holder could have a significant political impact at the national level.

Two reports were prepared by the Secretary General in 2005 and $2006 .{ }^{26}$ I will focus on the first, which provided an overview of the work of various treaty bodies and Special Procedures. It identified the CEDAW Committee as the body that: 'takes the most consistent and systematic approach to reviewing the persistence and impact of sex-discriminatory laws' ${ }^{27}$ The report found that most of the Special Procedure mandates did not focus on sex. ${ }^{28}$ However, the report did note that most of the new mandates now required the mandate holder to apply a gender perspective. ${ }^{29}$ The 2005 report considered the advisability of appointing a Special Rapporteur and suggested that such a mechanism would be an important tool in the implementation of Beijing, and also that it could complement the work of existing human rights bodies and Special Procedure mechanisms provided that there was not duplication. Such a mechanism would accelerate the realization of equality by providing the necessary momentum. ${ }^{30}$

The CSW took note of the report containing the OHCHR's and other views and asked for further 'views on ways and means that could best complement the work of the existing mechanisms and enhance the Commission's capacity with respect to discriminatory laws' for consideration at its 51st (2007) session.

In any event, the decision on whether or not to appoint a Special Rapporteur was postponed, yet again, in part due to the review of the Special Procedure mandates at the $\mathrm{OHCHR}^{31}$ (also under consideration

${ }^{26}$ CSW Advisability Report 2005. See also ECOSOC, Commission on the Status of Women, (on the Advisability of the Appointment of a Special Rapporteur on Laws that Discriminate against Women, 13 December 2006, E/CN.6/2007/8) [hereinafter CSW Advisability Report 2006]. The 2006 report complemented the previous report (CSW Advisability Report 2005 E/CN.6/2006/8), and 'should therefore be read in conjunction with it'.

27 CSW Advisability Report 2005, para. 16.

${ }^{28} \mathrm{Ibid}$. at para. 25. ${ }^{29} \mathrm{Ibid}$. at para. $27 .{ }^{30} \mathrm{Ibid}$. at para. 50.

${ }^{31}$ CSW Advisability Report 2007, E/CN.6/2007/8, para. 31, available at: http://daccessdds-ny.un.org/doc/UNDOC/GEN/N06/661/63/PDF/N0666163.pdf?OpenElement (last 
was the consolidation of the UN mechanisms working on 'women-related' issues). ${ }^{32}$ This review of the gender architecture ultimately led to the creation of the UN Entity for Gender Equality and the Empowerment of Women (UN Women) in 2010. ${ }^{33}$ The OHCHR suggested that a decision on the usefulness and viability of a Special Rapporteur be deferred to the CSW 52nd session (2008) in order to incorporate and build on the review's outcome. For its part, the OHCHR offered to prepare a report on the compatibility of the proposed mandate with the existing mechanisms. I was hired as the consultant to undertake this review and to prepare a report.

\section{The Banda Report on Laws that Discriminate against Women}

Commissioned in January 2007, the terms of reference of The Banda Report on Laws that Discriminate against Women ${ }^{34}$ required the consultant to review UN human rights mechanism $\mathrm{s}^{35}$ and the work of UN agencies working on women's rights. The aim was to ascertain to what extent the issue of laws that discriminate against women was being considered and whether a new mechanism was indeed necessary. The terms of reference also required the consultant to try to identify whether laws that discriminate against women continued to exist and the areas in which such laws were to be found. In light of the information gathered, the consultant was required to answer the question of whether a new special procedure mechanism was needed.

Meeting the objectives of the project necessitated the use of three data collection techniques. To address the issue of the work currently being undertaken within the UN required collecting and analyzing treaty body general comments, state reports, Concluding Observations and, where relevant, communications. Time constraints limited the consideration

accessed 14 February 2013). Equality Now 'Words and deeds: holding governments accountable in the Beijing +10 Review process' Women's Action 16.9, February 2007.

32 These were the Division for the Advancement of Women (DAW), International Research and Training Institute for the Advancement of Women (INSTRAW), Office of the Special Adviser on Gender Issues and Advancement of Women (OSAGI), United Nations Development Fund for Women (UNIFEM).

33 UNGA, System-wide Coherence, 21 July 2010, UN Doc. Assembly Res 64/289.

34 This is the name by which the report became known within the UN. CSW, 56th Session, Oral Statement by Kamala Chandrikirana, Chairperson of the Working Group on Discrimination against Women in Law and in Practice, New York, 5 March 2012. Available at: www.un.org/womenwatch/daw/csw/csw56/statements/Ch-P-working-group.pdf(last accessed 24 January 2013).

35 The terms of reference can be found in Appendix A in the Banda Report at 140-2. 
of state reports to the preceding five years. It also required examining the mandates of Special Rapporteurs. Reports of the Special Rapporteurs were further analyzed for their gender content. ${ }^{36} \mathrm{UN}$ documents on mainstreaming were also analyzed. Moreover, initiatives undertaken by UN agencies in the field of women's rights (including the girl child) were considered, and interviews held with UN officials in UNICEF (United Nations International Children's Emergency Fund), UNIFEM (United Nations Development Fund for Women), UNFPA (United Nations Fund for Population Activities), OSAGI (Office of the Special Adviser on Gender Issues and Advancement of Women) and IOM (International Organization for Migration) and DAW. A second data-collecting mechanism involved conducting interviews with UN officials and NGOs. This was to try to get the views of those charged with administering the system - did they consider a new mechanism necessary? What did their work involve? The NGOs provided the civil society perspective. I gave guarantees of anonymity to all UN personnel interviewed. I conducted interviews with UN human rights personnel at both the OHCHR in Geneva and also the human rights section and other agencies mentioned above at the UN headquarters in New York.

Finally, given that the focus of the project was on laws that discriminate against women, it was necessary to try to ascertain the extent to which such laws were still in existence. While the campaigning NGO Equality Now had already done excellent work producing a sample list of states with discriminatory laws and reproducing the offending provisions, it was still important to design and send out a questionnaire to ascertain the current position. ${ }^{37}$ The questionnaire was divided into seven parts (A-G) as follows:

Part (A) The Constitution and National Laws - provisions on equality and information on laws that discriminate against women.

Part (B) Responses to Discriminatory Laws - by governments, courts and civil society.

Part (C) Omissions and the Use of Temporary Special Measures

Part (D) The International and Regional Human Rights Systems - ratifications by state, participation by NGOs by way of shadow reports and dissemination of concluding observations of human rights committees nationally.

${ }^{36}$ Banda Report at 52.

37 Equality Now (2004), 'Words and deeds: holding governments accountable in the Beijing +10 Review process’, Women’s Action 16.6, Update March 2004. 
Part (E) Special Procedures - testing awareness of special procedure mechanisms. Had there been any engagement with special procedure mandate holders, and if there had been, the form of that engagement and the outcome.

Part (F) Advisability of Special Mechanism on Laws that Discriminate against Women - respondent's views on whether one was needed and reasons for this.

Part (G) Anything else - inviting respondents to comment on issues of interest, including regional perspectives on the issue of laws that discriminate against women and also the challenges of operating within plural legal systems. ${ }^{38}$

While de jure discrimination was the focus, the questionnaire made clear that information on de facto discrimination would also be welcome. In many states the law is complex, comprising plural normative systems including statute law, common law, customary laws and religious laws. These coexist, sometimes harmoniously, but often not. Indeed the adoption of the definition of discrimination found in Article 1 of the CEDAW, which encompasses de jure as well as de facto discrimination, made this a sine qua non. ${ }^{39}$ Moreover, evidence from state reports and general comments all pointed to the fact that de facto discrimination was a key factor in women's lack of enjoyment of their rights. ${ }^{40}$ The preamble to the questionnaire that went out said:

The project covers State sanctioned laws and regulations 'in all areas affecting women's civil, cultural, economic, political and social rights'. By State sanctioned is meant those laws that receive official recognition within the formal legal system.

${ }^{38}$ The full questionnaire and covering letter can be found in Appendix C of the Banda Report at 147.

39 A. Byrnes, 'Article 1', in M. Freeman, C. Chinkin and B. Rudolph (eds.), The UNConvention on the Elimination of All Forms of Discrimination against Women: A Commentary (Oxford University Press, 2012) 51-70 [hereinafter M. Freeman et al., CEDAW]. See also CEDAW General Recommendation 28 on the core obligations of States Parties under Article 2 of the Convention on the Elimination of All Forms of Discrimination against Women, UN Doc. CEDAW/AC/GC/28, 2010.

${ }^{40}$ See also CEDAW General Recommendation 21 on Marriage and Family Relations, UN Doc. HRI/GEN/1/Rev.9 (Vol. II), paras. 3, 12, 15, 24, 28, 33, 45, 46; CEDAW General Recommendation 23 on Women in Public Life, UN Doc. a/52/38/Rev. 1, paras. 9, 10; CEDAW Committee, Concluding Observations: Peru, 10 July 1998, UN Doc. CEDAW/C/ PER/3-4, paras. 313 and 317; CEDAW Committee, Concluding Observations: Mauritania, 11 June 2007, UN Doc. CEDAW/C/MRT/CO/1, paras. 15, 21 and 22; CEDAW Committee, Concluding Observations: Russian Federation, 30 July 2010, UN Doc. CEDAW/C/USR/ $\mathrm{CO} / 7$, para. 20. 
The questionnaire was sent to a wide variety of people in governments, UN agencies, academics and NGOs. ${ }^{41}$ In the introduction to the questionnaire, I encouraged the recipient to share the questionnaire. This snowballing technique is much used in social survey research. As with all questionnaire surveys including those administered, as in this case, by email, the response rate was at first slow. I had to follow up several times. The responses were variable. Some were comprehensive, sending in over twenty-five pages of cases, laws and views, while others only answered part of the questionnaire - largely to do with their views about whether there should be a mechanism.

I asked the OHCHR to have the questionnaire, which was in English, translated into at least three of the official UN languages (Arabic, French and Spanish), but only received the French version and this after two months of waiting. I think language was a barrier to some, particularly in the South and Central American region. One enterprising group in Francophone West Africa arranged for their own translation and were able to submit a response in a mixture of French and English (Franglais).

While chasing up questionnaires, I began going through all the documents that I had been given in Geneva and New York and of course all the treaty body material. From these, I learnt that a great deal had been done within the UN on women's rights. Initiatives included the institution-wide mainstreaming initiative, which required all institutions to take account of the need to integrate a gender perspective into their work. ${ }^{42}$ In Special Procedures, this saw more mandates being created with a specific gender focus. Most impressive in their focus on women's rights were Special Rapporteurs on indigenous people, minorities, health and superlatively the Special Rapporteur on Housing, who had written a series of reports that had included consultation with the CEDAW Committee about the possibility of a General Recommendation on women and the right to housing. ${ }^{43}$ However, the statistics on the number of communications sent to Special Procedures were, when disaggregated by sex, unedifying. Specifically, in 2005 only 13 per cent were sent by women. Men accounted for 76 per cent, with 7 per cent not having the sex of the applicant recorded. The paper

${ }^{41}$ A list of respondents to whom the questionnaire was sent or from whom responses were received is listed in Appendix D of the Banda Report at 152.

${ }^{42}$ Report of the Secretary General on the Question of Integrating the Human Rights of Women Throughout the United Nations System, 25 March 1998, E/CN.4.1998/49. UN, Integrating a Gender Perspective into the Work of the United Nations Treaty Bodies, 3 September 1998 HRI/MC/1998/6. See generally the Banda Report at 41-53.

${ }^{43}$ See also Ikdahl in this volume. 
trail also showed that treaty bodies were more directed in their questioning of States Parties on issues pertaining to the enjoyment or otherwise by women of their rights. There was greater cross-pollination between Committees, which often referred to Concluding Observations made by their peers on other Committees in dialogue with states. Moreover, the General Comments of treaty bodies showed greater attention being paid to the ways in which women experienced discrimination. ${ }^{44}$ Again, not surprisingly, the CEDAW Committee emerged as the committee that was most focused in the attention it paid to women's lives and rights.

I started interviews in Geneva, where I spoke to the research and support personnel for a number of Special Rapporteurs, ${ }^{45}$ people in both the regional human rights offices as well as those working directly with the main treaty bodies and finally with the Secretariat in the Special Procedures sections. I got the impression from the Geneva leg that many staff were reticent about the creation of a new mechanism, using words like 'duplication' and 'wasteful' while also citing (human) resource shortage, which they linked to their own exhaustion. Some seemed jaded by the whole process, with one asking:

If there are 41 Special Rapporteurs, do we need another? It is not about numbers but about whether the need is there. It may be political - will the Council approve it? Let's look at what we have in all parts of the house, especially when CEDAW comes here (to Geneva), see what our strengths are and what we can do together. We need to know what we have. ${ }^{46}$

This reticence, I must hasten to add, was not universal - some did speak out in favour of a new mechanism, with one observing that one person's duplication was another's focus, and another noting:

Why do we have a Special Rapporteur on Torture and also a Torture Committee? Maybe it is seen as immediate and also that it matters. I guess they just don't rate women very highly or maybe they are afraid of the reaction in the (Human Rights) Council. ${ }^{47}$

It is also worth noting that the idea of a having a Working Group rather than just one Special Rapporteur came from a UN official in Geneva. The

44 Banda Report at 41-55.

45 They assist the Special Rapporteur who are part-time appointees having full-time jobs elsewhere.

46 Banda Report at 118.

47 Cited in the Banda Report at 123. See also N. Rodley, 'United Nations human rights treaty bodies and special procedures of the Commission on Human Rights - complementarity or competition?', Human Rights Quarterly 25:4 (2003) 882-908. 
NGOs that I met with in New York including the Centre for Reproductive Rights, Human Rights Watch Women's Division and Equality Now, were unilaterally positive and supportive of the idea and in the case of Equality Now, not surprisingly so.

\section{Questionnaire responses}

An analysis of the questionnaire responses focusing on the laws identified as discriminating against women showed that even (the majority of) those states that had constitutions guaranteeing equality before the law had laws that discriminate against women. Personal status laws were identified as the most problematic. Discriminatory provisions were found in laws enshrining a lower age of marriage for girls than boys and, in some cases, sanctioning child marriage, paternal power vis-à-vis decisions concerning the child that was often linked to marital power over the wife, discrimination in nationality and citizenship laws, different grounds for divorce, and discriminatory property division on death and divorce. Even procedural laws were sometimes found to be discriminatory, privileging male witnesses over female ones. Discriminatory practices and provisions were also identified in employment law and criminal law. The discriminatory laws echoed the state reservations to the CEDAW. ${ }^{48}$ Disturbingly the directly legally discriminatory laws came primarily, though not exclusively, from southern states (northern states had discriminatory laws on succession to monarchies). ${ }^{49}$

\subsection{To have a mechanism or not}

Those who were opposed or sceptical about the need for the creation of a new mechanism argued the following in outline:

(i) that the creation of a new mechanism would result in duplication and it would take away from the work of the CEDAW Committee;

(ii) other committees would stop focusing on women's rights issues;

(iii) that there was already a Special Rapporteur dealing with violence against women; and

(iv) that a focus on de jure discrimination was not helpful.

${ }^{48}$ See also J. Connors, 'Article 28', in M. Freeman et al., CEDAW, 565-95.

49 Banda Report at 56-115. 
These arguments were considered in turn. ${ }^{50}$ Of these four, the first on duplication was the most often repeated. The duplication was said to be with the CEDAW Committee and the rest of the human rights treaty bodies and with the Special Rapporteurs on Violence against Women and Trafficking. ${ }^{51}$

Those in favour of the creation of a separate mechanism argued that the CEDAW Committee and a new Special Rapporteur on laws that discriminate against women should be seen as complementary mechanisms. They identified shortcomings in the treaty-based system, highlighting the problems of missing and incomplete reports. Indeed the CEDAW Committee itself identified thirteen states that had not reported for more than ten years; thus there could be no dialogue or engagement with them. ${ }^{52}$ Further, proponents of a new special mechanism noted that human rights committees had limited resources for follow-up, which led to Concluding Observations being ignored and thus no state accountability. While some committees had complaints mechanisms, these had not been ratified by all the states that were parties to the main convention or treaty, thus highlighting their limitations. Moreover, the low usage by women of the complaints mechanisms of both Special Procedure and treaty bodies did not bode well for systematically tackling discriminatory laws. It was argued that a new Special Rapporteur could assist the CEDAW Committee by following up on its (and indeed other committees') Concluding Observations vis-à-vis laws that discriminate against women. Indeed, it was noted that the CEDAW Committee could issue instructions to the Special Rapporteur about states that needed following up and that the two would have a symbiotic, cooperative relationship.

The Special Rapporteur could maintain an ongoing dialogue with States Parties and undertake thematic surveys as well as sharing data on good practice. It was also noted that there were examples of other treaty bodies having 'duplicated' Special Procedure mechanisms, and that these

50 The arguments echoed those articulated by states and other consultees in CSW Advisability Report 2006, paras. 10-29.

${ }^{51}$ I personally found this argument frustrating, suggesting as it does that violence against women is the only violation that women face. There was also a hint of 'we have "given them" two mechanisms already (plus CEDAW), what more do they want?' See also R. Kapur, "The tragedy of victimisation rhetoric: resurrecting the "native" subject in international post-colonial feminist legal politics', Harvard Journal of Human Rights 15 (2002) 19-54.

52 CEDAW, 'Ways and means of expediting the work of the Committee on the Elimination of All Forms of Discrimination against Women: Note by the Secretariat', CEDAW/ C/2007/1/4, Annex III. 
operated without undue overlap. NGOs working on women's rights were particularly keen on the appointment of a new Special Rapporteur, seeing him or her as enhancing their lobbying and educational work within their home jurisdictions..$^{53}$ Additionally, a Special Rapporteur was said to be important in strengthening mainstreaming across all the entities of the United Nations.

Acknowledging the work of the human rights treaty mechanisms on women's rights issues, but still arguing for a new mechanism, was law professor Catherine Mackinnon:

Discriminatory laws pervasively continue to exist, present mechanisms having barely begun to scratch their surface, far less to solve the problems they pose. A special mechanism would build upon and support the work of CEDAW and others in this area, including by generating the on-going continuous (rather than periodic) dialogue with countries that no current mechanism can. It would also heighten the visibility of discriminatory laws internationally, including by reporting directly to the Human Rights Council, highlighting the issue as a priority in the human rights field. Further, while some features of discrimination against women by law are simple and blatant, others interface in more subtle and complex ways with women's inequality as a whole. All the dimensions of de jure discrimination are more likely to emerge when investigated together in mutual comparative light. Current international mechanisms by design can only address these issues one country at a time. A complementary mechanism like a Special Rapporteur would offer the unique resources and mandate to approach the problem systematically on the global scale on which it exists. From the cumulative interconnections, patterns, and themes that can only be discerned in an overarching cross-cutting transnational inquiry, fresh and effective approaches to legal equality for women could emerge. ${ }^{54}$

On balance, the consensus came down in favour of the appointment of a special mechanism that should expand beyond de jure to also look at discrimination in practice. Furthermore, it was suggested that consideration be given to issues pertaining to implementation, access to justice and enforcement. Also included in a proposed mandate was the identification of examples of good practice. Cooperation with regional mandates, especially the Inter-American and African Special Rapporteurs on women's

${ }^{33}$ Supporters included the Malaysian-based Sisters in Islam, Zambian-based WILDAF (Women in Law and Development in Africa), Jerusalem-based Women's Centre for Legal Aid and Counselling, Nepal-based Foundation for Women, Law and Development, and a Tanzanian-based organization. See the Banda Report at 127-31.

${ }^{54}$ Professor Catherine Mackinnon as cited in the Banda Report at 124-5. 
rights, was mooted. Clearly a mapping exercise of existing laws would need to be done, both by looking at Concluding Observations of all the human rights treaty bodies as well as by means of independent research.

Published in March 2008, the report received a great deal of support from the then High Commissioner for Human Rights, Louise Arbour. The High Commissioner used the report as the basis for her 2008 Women's Day statement in which she asked for states to review and repeal any discriminatory laws. ${ }^{55}$ The report also formed the basis of the annual Inter-Parliamentary Union conference held later that year. ${ }^{56}$ Parliamentarians from around the globe discussed and brought examples of progressive laws passed, while also acknowledging legislative gaps that remained.

\section{Negotiations for a mandate on laws that discriminate against women}

The Human Rights Council considered the matter of whether to have a Special Rapporteur in 2009. A Council resolution sponsored by thirty-eight States Parties from Africa, Europe, North and South America, and the Middle East (Israel) ${ }^{57}$ identified why dealing with laws that discriminate was important:

The Human Rights Council recognises that women's inequality before the law has resulted in the lack of equal opportunities for women in education, access to health, economic participation, access to labour and disparities in salaries and compensation, public and political participation, access to decision making processes, inheritance, ownership of land, financial services, including loans and nationality and legal capacity among others, as well as increased vulnerability to discrimination and violence and that all countries face challenges in these areas. ${ }^{58}$

The resolution welcomed the work done by the CEDAW Committee on women's equality. It also recognized the work done by the Human Rights

55 OHCHR, 'Women are still discriminated against in all countries, says UN Human rights chief' 7 March 2008, available at: http://reliefweb.int/node/259520 (last accessed 9 June 2012).

${ }^{56}$ Inter-Parliamentary Union with the Office of the High Commissioner for Human Rights, Sixth Information Seminar on Parliaments and CEDAW: Addressing Laws that Discriminate against Women, Geneva, 16 October 2008. See www.ipu.org/splz-e/ cedaw08.htm (last accessed 23 March 2012).

57 Human Rights Council, 'Elimination of discrimination against women', 1 October 2009, A/HRC/12/L.3/Rev.1.

58 Ibid. at para. 6. 
Council in 'addressing the issue of discrimination against women in both law and practice' and called for half a day to be set aside to discuss the issue of discrimination against women. ${ }^{59}$ This duly took place with panellists including one CEDAW Committee member as well as an academic, a representative from UNIFEM and the Special Rapporteur on violence against women. ${ }^{60}$

Further, the Council decided to ask for a report to be prepared on the need for a mechanism. ${ }^{61}$ This was done in house by the OHCHR and, like most UN documents, merely reiterated the litany of existing documents that had gone before on the matter. ${ }^{62}$ It recalled the international human rights framework on non-discrimination, highlighting the CEDAW Committee's call for the use of substantive equality, which covered direct and indirect discrimination as well as that grounded in gender stereotypes. This in turn called for 'systemic and structural transformation of institutions and attitudes that reflect and entrench discrimination against women'. ${ }^{63}$ The Thematic Study made the link between equality and the attainment of the Millennium Development Goals (MDGs), especially MDG 3 Gender Equality. ${ }^{64}$

Recommendations included making a consideration of laws that discriminate against women a standing item on the list of questions that states have to address in the Universal Peer Review process. Moreover, it was suggested working with UN Women to ensure that the focus of its new work plan included equality before the law. The new mechanism could also perform a consolidating function, drawing and building on the findings of the CEDAW Committee and other treaty bodies.

The OHCHR Thematic Study 2010 concluded that, notwithstanding existing treaty bodies and Special Procedure mechanisms, there was still scope for a new mechanism and recommended that the

${ }^{59} \mathrm{Ibid}$. at paras. 10 and 11 . See also para. 16 on the half-day.

${ }^{60}$ 15th Session of the HRC, Panel Discussion on elimination of discrimination against women, Room XX, Palais des Nations, Geneva, Monday 20 September 2010.

${ }^{61}$ HRC, 'Elimination of discrimination against women', paras. 15 and 16.

${ }^{62}$ Human Rights Council, Thematic Study of the Office of the United Nations High Commissioner for Human Rights on Discrimination against Women, in Law and Practice, and How the Issue is Addressed Throughout the United Nations Human Rights System, 30 August 2010, A/ HRC/15/40, paras. 3 and 51 [hereinafter OHCHR Thematic Study 2010].

${ }^{63} \mathrm{Ibid}$. at para. 10. See also para. 11. CEDAW General Recommendation 25 on Temporary Special Measures, para. 8 and CEDAW General Recommendation No. 28 on State Obligations.

${ }^{64}$ OHCHR Thematic Study 2010. 
Council follow it up. Recommendations included working with the International Parliamentary Union to lobby states to amend laws. The new mechanism should also have the ability to investigate and suggest model laws.

Finally in October 2010, the matter was again considered by the Human Rights Council. A resolution was proposed by Mexico with Columbia to set up a working group of five independent experts who were to have three years to conduct their work in the first instance. Worthy of note is the last-minute attempt by Saudi Arabia to include an amendment:

ABDULWAHAB ATTAR (Saudi Arabia), speaking in a general comment, said Saudi Arabia suggested a small amendment of the Operational Paragraph 1 to the draft resolution L.15. 'We call upon States to take all appropriate measures in accordance with their international commitments under international human rights law to eliminate discrimination against women by any person, organization, or enterprise.' The paragraph had been approved in many past resolutions and Saudi Arabia was merely requesting an addition that had been approved by the Council on earlier occasions.

In effect, Saudi Arabia was seeking to add the words: 'We call upon States to take appropriate measures in accordance with their international commitments' ${ }^{65}$ to the Human Rights Council's 2009 resolution, which, echoing CEDAW Article 2(d), reads: 'reaffirms the obligations of States to take all appropriate measures to eliminate discrimination against women by any person, organization or enterprise'. ${ }^{66}$ The Saudi position is notable for its remarkable consistency in arguing that respect for municipal cultural-religious frameworks should prevail over international human rights norms. ${ }^{67}$ Indeed, the Saudi reservation to Article 2 of the CEDAW on state obligations explains that it is ratifying on the understanding that the Convention is to be interpreted according to Saudi laws including religion (Shariah), a stance objected to by European states as being in violation of

${ }^{65}$ OHCHR, 'Human Rights Council establishes Working Group on Discrimination against Women in Law and Practice', Human Rights Council, Morning, 1 October 2010. A disclaimerattached to this document notes 'for use of media, not an officialrecord', available at: www.ohchr.org/en/NewsEvents/Pages/DisplayNews.aspx?NewsID=10405\&LangID=E (last accessed 9 June 2012) [hereinafter OHCHR News 2010]. Emphasis added.

${ }^{66}$ A/HRC/12/L.3/Rev.1, 1 October 2009, para. 1.

67 Saudi Arabia had tried the same during the drafting of the UDHR. S. Waltz, 'Universal human rights: the contribution of Muslim states', Human Rights Quarterly 26:4 (2004) 799-844, at 819-25. See also K. Hashemi, 'Religious legal traditions, Muslim states and the Convention on the Right of the Child: an essay on the relevant UN documentation', Human Rights Quarterly 29:1 (2007) 194-227, at 202, 207-15. 
both the object and purpose of the CEDAW under Article 28(2) and the Vienna Convention on the Law of Treaties $1968 .{ }^{68}$

Debate raged about both the aim of the Saudi proposed amendment and also whether it should be permitted to seek to amend a resolution at that (late) stage in the proceedings. States including Bahrain, Djibouti, Libya, Jordan and Pakistan argued in favour of the right of Saudi Arabia to seek to make a last-minute amendment and said that it could be incorporated without adverse effect on the general tenor of the resolution. China noted that it:

[F]ully agreed with ... and supported the amendment put forward by Saudi Arabia, as China believed that the protection and promotion of human rights was ultimately the task of national Governments, in accordance with their commitments under international law to protect and promote women's rights and eliminate discrimination. Governments should not only act in line with international agreements, but also in line with the consensus agreed upon in the international community to protect and support the rights of women. ${ }^{69}$

Similarly, Libya argued that it:

[B]elieved that under all religions women enjoyed their rights and were respected and valued. Libya would fully support the amendment and said that everyone should understand the relativism of some concepts; there might be divergences in cultures and religions and it was the diversity that made the world what it was. No country should have anything imposed on them without that country being a party to a particular international instrument. ${ }^{70}$

There were many rejoinders including from the United States and the United Kingdom, together with representatives speaking on behalf of the Africa group and the European Union. The culmination came when co-resolution sponsor Mexico noted that there had been extensive consultation enabling comments and amendments to be incorporated before the resolution had been tabled. It noted that in addition to Colombia, there were sixty co-sponsors of the resolution and that while there had

${ }^{68}$ Reservations to CEDAW and objections, available at: www.un.org/womenwatch/daw/ cedaw/reservations-country.htm (last accessed 23 March 2012). Vienna Convention on the Law of Treaties, 1155 UNTS 331, entered into force 27 January 1980, Article 19. See CEDAW Committee, List of Issues and Questions with regard to Consideration of Periodic Reports: Saudi Arabia, 16 August 2007, UN Doc. CEDAW/C/SAU/Q2, para. 2. See also CEDAW Committee, Concluding Observations: Saudi Arabia, 8 April 2008, UN Doc. CEDAW/C/SAU/CO/2, paras. 9 and 12.

69 OHCHR News 2010.

${ }^{70}$ Ibid. 
in the past been 'caveats to the application of certain rights that were not absolute rights', it further noted:

The problem was that in this specific paragraph, the subject was discrimination against women, full stop. It was not a discussion of norms or of distinct ways of implementing laws. The Council could not accept a caveat or a reservation along the proposed lines when what it was talking about was discrimination against women. For reasons of principle, the proposed forms of words could not be accepted. There was no single law that could prevent discrimination against women, and this was why there could be no weakening of the rights of women by using the form proposed. The Human Rights Council could not accept reservations, limitations or caveats which would mean that it was questioning the absolute right women had to not be discriminated against, be it under the law or in any other fashion. The concerns of those supporting the resolution were fully reflected in the resolution and in the mandate of the Working Group. ${ }^{71}$

The argument that the principle of non-discrimination was non-derogable won the day. The proposed amendment was voted on, with 18 in favour, 22 against and 4 abstentions. ${ }^{72}$ The amendment was therefore rejected. However, the closeness of the figures for and against (which become equal if one factors in the abstentions) suggests the points of resistance and challenge that will face the Group of five going forward. The resolution was adopted without a vote. ${ }^{73}$ Against all hope and expectation, a new mechanism was approved..$^{74}$

\section{The new Working Group}

On 8 October 2010 the UN Human Rights Council decided to establish, for a period of three years, a new Working Group of five independent experts, of balanced geographical representation, on the issue of discrimination against women in law and in practice. ${ }^{75}$ While a single

${ }^{71}$ Ibid.

72 OHCHR, 'Human Rights Council establishes Working Group on Discrimination against Women in Law and Practice', Human Rights Council, 1 October 2010.

${ }^{73}$ See generally, Human Rights Council, Report of the Working Group on the Issue of Discrimination against Women in Law and in Practice, 5 April 2012, A/HRC/20/28, para. 8 [hereinafter Working Group Report 2012].

${ }^{74}$ Asked publicly about my own assessment of the likelihood of a new mechanism being created, I was sceptical, noting 'Turkeys don't vote for Christmas.' I am pleased to have been proved wrong.

${ }^{75}$ Human Rights Council Resolution, $15 / 23$ on the Elimination of Discrimination against Women, 8 October $2010 \mathrm{~A} / \mathrm{HRC} / \mathrm{RES} / 15 / 23$ [hereinafter HRC, Elimination of Discrimination]. 
Special Rapporteur had been mooted for a long time, the appointment of a Working Group seems to be the right decision. A subject as broad, complex and fraught as discrimination against women in law and practice is best addressed by a group of people from all the major regions and legal systems of the world. Each member will have specialist knowledge not only of the law, but of the areas of controversy and of current practice and trends. Moreover, given the tendency to label issues of equality as 'emanating from the West' and calling women from the global South who work for equal rights 'westoxified', it seems wise to have included a global balance in the membership of the group. ${ }^{76}$ They can give each other cover and support when the name-calling inevitably begins. Equally important is the expansion of the mandate beyond formal laws to include practice.

The mandate of the Working Group required it:

(a) to develop a dialogue with states, the relevant UN entities, national human rights institutions, experts on different legal systems and civil society organizations to identify, promote and exchange views on best practices related to the elimination of laws that discriminate against women in terms of implementation or impact and, in that regard, to prepare a compendium of best practices;

(b) to undertake studies in cooperation with and reflecting the views of states and relevant UN entities on ways and means in which the Working Group can cooperate with and fulfil its mandate;

(c) to make recommendations on the improvement of legislation and implementation of law to contribute to the realization of Millennium Development Goal number three on gender equality;

(d) to work with other Special Procedure mechanisms and CEDAW together with UN Women with a view to avoiding duplication;

(e) to consult relevant stakeholders including regional and national human rights mechanisms; and

(f) to compile a report on good practices in eliminating discrimination against women. ${ }^{77}$

76 'Westoxification' is a term coined by Uma Narayan to describe the phenomenon of silencing outspoken 'local women' by discrediting them as a-cultural and 'brainwashed' by the 'West'. U. Narayan, Dis/locating Cultures/Identities, Traditions, and Third World Feminism (New York: Routledge, 1997).

77 HRC, Elimination of Discrimination, para. 18, available at: www2.ohchr.org/english/ bodies/hrcouncil/docs/15session/A.HRC.RES.15.23_En.pdf (last accessed 14 February 2013). 
The Resolution also called on agencies within the United Nations and other groups including NGOs to cooperate fully with the Working Group in the fulfilment of its mandate. ${ }^{78}$ The CSW was explicitly mentioned as one of the entities to which the Working Group had to submit its reports. $^{79}$

The call for nominations for the five Working Group members duly went out. ${ }^{80}$ Out of a total of 245 names put forward, a shortlist of 15 was drawn up. ${ }^{81}$ Final selection took place at the Human Rights Council meeting in March 2011. The five members of the Working Group, all women, who were appointed by the Human Rights Council in March 2011 and assumed their functions on 1 May 2011, are Kamala Chandrakirana (Indonesia); Emna Aouij (Tunisia); Mercedes Barguet (Mexico); Frances Raday (Israel/ United Kingdom); and Eleonora Zielinska (Poland) ${ }^{82}$ Of these two, Emna Aouij and Frances Raday have served as CEDAW Committee members. All have extensive expertise in women's rights. ${ }^{83}$

In formulating its work plan, the Working Group decided to have one member take the position of Chairperson on an annual basis. ${ }^{84}$ The founding Chairperson is Kamala Chandrakirana. Initially the Working Group identified four thematic areas falling under four broad categories:

(1) public life and citizenship including nationality and citizenship laws and political representation for women;

(2) economic life including employment laws, wage gaps, access to goods and services, economic exploitation of women's sexuality in trafficking and pornography, policies, practices and codes related to business, transnational corporations and natural resource management;

(3) family life including religious and customary personal law, forced marriage, child marriages; and

${ }^{78}$ Ibid. at para. $20 . \quad{ }^{79} \mathrm{Ibid}$. at para. 21.

80 Action Canada for Population Development and others, 'Proposed criteria for the selection of candidates for the UN Working Group on Discrimination against Women', 11 November 2010.

${ }^{81}$ Human Rights Council, Letter from Sihasak Phuangkethkeow, President of the Human Rights Council to All Permanent Representatives to the Human Rights Council, Geneva, 1 February 2011.

82 'OHCHR Working Group on the issue of discrimination against women in law and in practice'. See: www.ohchr.org/EN/Issues/Women/WGWomen/Pages/WGWomenIndex. aspx (last accessed 23 March 2012).

${ }^{83}$ Ibid.

${ }^{84}$ Working Group Report 2012. 
(4) health and safety including reproductive rights, violence against women, women in detention and maternal mortality. ${ }^{85}$

Thereafter a fifth, violence against women, was added as a cross-cutting category.

In its first work plan covering 2012-2013, the WG has elected to focus on public and political life and social and economic life. It is the first issue that is the current subject of research with the WG looking at efforts undertaken in times of political transition, particularly transitions that involve fundamental changes of political regime and/ or of the legal system. In gathering data, the WG has written letters and devised a simple one-page questionnaire requesting information from governments and other interested stakeholders. It is interested in discriminatory constitutional and legislative provisions, including on violence against women as well as information on women's access to justice within societies in transition. The second theme on social and economic life is to be tackled in $2013 .^{86}$ Parallel to this process is the Working Group's compilation of a compendium of what it has decided to term 'good or promising practice ${ }^{\text {'87 }}$ for presentation to the Human Rights Council. ${ }^{88}$

Although still in its infancy, the WG has shown itself to be remarkably astute in its chosen areas of focus, which are both topical in light of the multiple ongoing political revolutions as well as in light of the severe economic climate that has had a huge impact on women's lives and access to social and economic rights. ${ }^{89}$ Moreover, the concentration on economic and social life in 2013 will help to draw attention to Millennium Development Goal 3 on Gender Equality, just as the 2015 deadline for the culmination of progress towards meeting the goals comes into view. The two topics have, of course, the added advantage of being far less contentious than other possible areas of focus including health and safety (if

${ }^{85}$ OHCHR Briefing note, 1st session of the Working Group on Discrimination against Women in Law and Practice - Geneva, 6-10 June 2011. Available at: www.ohchr.org/EN/ Issues/Women/WGWomen/Pages/FirstsessionWG.aspx (last accessed 20 March 2012).

${ }^{86}$ OHCHR Working Group on Discrimination against Women in Law and Practice, 'Methods of work', available at: www.ohchr.org/EN/Issues/Women/WGWomen/Pages/ MethodsOfWork.aspx (last accessed 4 April 2012). See also Working Group Report 2012.

87 Working Group Report 2012, para. 18.

${ }_{88}$ The Resolution mandates that the group uses good practice and best practice interchangeably. Compare HRC, Elimination of Discrimination, para. 18(a) and (f). A discussion of the use of 'good, best or promising practice' is beyond the scope of this chapter.

89 Working Group Report 2012, paras. 32-5. 
this covers abortion law). This long-term strategic approach augurs well for a renewal of the WG mandate, which will then, hopefully, lead to a bolder approach to women's rights by engaging with controversial issues. Equally important will be its relationship with the CEDAW Committee and UN Women. Contacts have been made with both bodies and, given the shared objective of ending discrimination against women in law and practice, good working relationships seem assured. At its first session the WG undertook 'to firstly build an information base from the concluding observations of CEDAW and other treaty bodies' ${ }^{\prime 0}$ and to 'explore the availability of statistical data 30 years after CEDAW to show in a dynamic way progress in women's situation particularly in public and economic life'. ${ }^{11}$ The WG also undertook to develop 'a qualitative mapping of available sources of information'.92 The Human Rights Council Resolution setting up the Working Group decreed that the WG should report to both the CSW and the Council. In her first address to the CSW, the Chairperson of the Working Group noted that she saw the CSW annual meeting as an important place to raise issues of equality of women and to engage with governments, NGOs and other stakeholders. In conclusion, she hoped for 'continuous and effective coordination between the Human Rights Council and its Special Procedures and CSW in the spirit of promoting a coherent approach in overcoming the remaining obstacles to full equality and women's human rights by the various bodies and mechanisms within the United Nations'. ${ }^{93}$

Going forward, there is room for optimism. ${ }^{94}$

90 To mark the establishment of the Working Group, Equality Now prepared a report: 'Discrimination against women in law: a report drawing from the Concluding Observations of the Committee on the Elimination of Discrimination against Women', May 2011. See also, J. Hunt, 'UN Working Group on Discrimination against Women in Law and Practice', prepared for Advocates for International Development, 3 August 2011.

${ }^{91}$ OHCHR Briefing note - 1st session of the Working Group on Discrimination against Women in Law and Practice, Geneva, 6-10 June 2011. In its first report the Working Group cited the CEDAW Committee and Human Rights Committee general comments as guides to its work. See Working Group Report 2012, paras. 25 and 26.

92 Useful may be M. Freeman et al., CEDAW. See also UNIFEM, Translating CEDAW into Law: CEDAW Legislative Compliance in Nine Pacific Island Countries (Suva: UNIFEM, 2007); UNIFEM, Gender Equality Laws: Global Good Practice and a Review of Five South East Asian Countries (Bangkok: UNIFEM, 2009).

${ }_{93}$ K. Chandrakirana Oral Statement at 3.

${ }^{94}$ Ibid. at 2-3. 


\section{Opportunities}

Equality Now started its February 2010 update on the laws that discriminate by highlighting that it was 'pleased to report that more than half of a total of 52 countries highlighted in both previous reports have fully or partially repealed or amended the discriminatory laws indicated'. ${ }^{95}$ The integration of a gender perspective into the work of all UN human rights committees and agencies, while not perfect, is a cause for further optimism, not least because it will mean that the Working Group is being assisted in its work on many fronts, which can only be good for meeting the challenging objective of eliminating discrimination against women in law and practice. ${ }^{96}$ The CEDAW Committee and indeed the human rights treaty bodies have considerably extended the understanding of equality beyond a formal model requiring legal change. Substantive equality requires closer attention to be paid to the factual situation of women including historical inequalities and deploying, if necessary, the use of temporary special measures. An intersectional analysis of discrimination is key. ${ }^{97}$ Also worthy of note is the adoption by the CEDAW Committee and others of transformative equality, which involves engaging with structural discrimination grounded in culture, which augurs well for the Working Group as its performs its mandate. ${ }^{98}$ Moreover, the CEDAW Committee, with which the Working Group will work closely and with which it has already held consultative meetings, has ramped up its consideration of legal discrimination, and one can now see in Committee reports subsections specifically addressing laws that discriminate against women..$^{99}$ The Committee now also has follow-up procedures for engaging States

${ }^{95}$ Equality Now, 'Words and deeds: holding governments accountable in the Beijing +15 Review process' Update: Women's Action 16.10, February 2010 at 1.

${ }^{96}$ UN Women, In Pursuit of Justice: 2011-2012 Progress of the World's Women (New York: UN Women, 2011).

97 CEDAW General Recommendations 25 and 28. See also CEDAW Committee, Concluding Observations: Norway, 2 March 2012, UN Doc. CEDAW/C/NOR/CO/8, paras. 9-10, 18, $21-23$.

98 The jurisprudence of the Committee under the Optional Protocol to CEDAW has been impressive. Some examples include A.T. v. Hungary, CEDAW/C/36/D/2/2003; A.S. v. Hungary, CEDAW/C/36/D/4/2004; Fatma Yildirim (deceased) v. Austria, CEDAW/C/39/ D/6/2005; Vertido v. The Philippines, CEDAW/C/46/D/18/2008; and R.K.B. v. Turkey, CEDAW, Comm. No. 28/2010, UN Doc. CEDAW/C/51/D/28/2010. See also, R. Holtmaat 'Article 5' in M. Freeman et al., CEDAW, 122-67.

99 CEDAW Committee, Concluding Observations: Uganda, 5 November 2010, UN Doc. CEDAW/C/UGA/CO/7 (2010), paras. 11 and 12. 
Parties. ${ }^{100}$ Crucially the Working Group intends to receive information from a range of sources and to use communications 'with Governments and other actors in a spirit of soliciting dialogue on issues falling within its mandate'. Hopefully the 'appropriate action' that it promises to take will yield cooperation and positive results. ${ }^{101}$ At the regional and national levels there are many positive developments in norm making, including new protocols, policies and constitutions. ${ }^{102}$ Moreover, national courts have proved adept at progressing the equality and women's human rights agenda. ${ }^{103}$

Given the historical resistance to the idea of women's rights, these positive elements have to be tempered with a dose of realism. The last section looks briefly at some of the challenges that will face the Working Group.

\section{Challenges}

The breadth and scope of the Working Group's mandate requires it to traverse legal, economic, socio-religious and cultural terrain. In engaging states, the Working Group will be faced with the 'who are you to tell us how to order our societies?' phenomenon. The resistance of states to change can be seen in the difficulties faced by human rights committees in getting states to lift reservations, particularly those related to the CEDAW. ${ }^{104}$ If states fail to comply with voluntarily entered into agreements, then what are the chances that they will listen to the Working Group? There is a direct correlation between those states that were resistant to the setting-up

100 CEDAW Committee, Concluding Observations: India, 22 October 2010, UN Doc. CEDAW/C/IND/CO/SP.1 (2010).

101 Working Group Report 2012, para. 40.

102 See for example Council of Europe Convention on Preventing Violence against Women and Domestic Violence, ETS 210, not yet in force. See also African Union Decade for Women, AU Assembly Dec. 487 (XIX) declaring 2010-2020 as African Women's Decade. Articles 27(3) and 27(4) of the Constitution of Kenya, 27 August 2010.

${ }^{103}$ M. Ssenyonjo, 'Women's right to equality and non discrimination: discriminatory family legislation in Uganda and the role of Uganda's constitutional court', International Journal of Law Family and Policy 21:3 (2007) 341-72. Rono v. Rono (2005) AHRLR 107 (KeCA 2005); In Re Estate of Lerionka Ole Ntutu, Succession Cause No. 1263 OF 2000, 2008 Eklr 1; Noorfadilla Binti Ahmed Saikin v. Chayed Bin Basirun, Originating Summons No. 21-248-210, Malaysian High Court at Shah Alam; Fornah v. Secretary of State for the Home Department [2006] UKHL 46; Shilubana and Others v. Nawmitwa 2008 (9) BCLR 914 (SA CC); Law \& Advocacy for Women in Uganda v. Attorney General (Constitutional Petition No. 8 of 2007), [2010] UGCC 4. IACtHR; González et al. ('Cotton Field') v. Mexico, Judgment, 16 November 2009.

104 Connors, 'Article 28' at 573-5. 
of a Working Group and those with the most problematic reservations, including to provisions relating to state obligations under Article 2 of the CEDAW. Challenging religious laws, even with the benefit of different interpretations preferred by academics and religious progressives, will remain controversial and difficult. Moreover, given the existence of plural normative orders in many jurisdictions, saying states are responsible for violations of rights by non-state actors (including discriminatory laws outside the state's direct control) is legally accurate and indeed taken for granted in academic discourse, but much harder to monitor, evaluate and change in practice.

There is of course the gap between law and practice in all states. There are many states that do not have laws that are facially discriminatory, but still discrimination persists. The discrepancy in pay between men and women is such an example. In the United Kingdom the pay gap between men and women has persisted and 'progress towards the eradication of the wage gap between men and women has stalled, especially in the private sector and for persons employed in part-time work'. ${ }^{105}$ The figures are even worse for migrant women and men. How should this be dealt with? Linked to this are challenges in quantifying women's domestic labour on the ending of marital contracts when women's unpaid work is taken for granted and as comprising part of the gendered bargain of marriage. ${ }^{106}$

Given the seeming intractability of gender stereotyping, there is the ongoing question about how to tackle its pervasive and often negative impact on institutional frameworks that exist to protect women. ${ }^{107} \mathrm{~A}$ pressing example is the low conviction rate in rape cases in some states, which can be explained in part by institutional (police and prosecutorial) failure to rise above and indeed challenge pervasive gender stereotyping of the 'kind of woman who gets raped' and who may thus have 'deserved

105 CESCR Committee, Concluding Observations: United Kingdom of Great Britain and Northern Ireland, the Crown Dependencies and the Overseas Dependent Territories, 12 June 2009, UN Doc. E/C.12/GBR/CO/5, para. 18.

106 See in particular the dissenting opinions in B.J. v. Germany, CEDAW Communication 1 of 2003, Decision of 14 July 2004 (inadmissible) appendix. See also dissenting opinion of Hale, LJ in the UK Supreme Court decision of Radmacher v. Granantino [2010] UKSC 42.

107 See also R. Holtmaat, 'CEDAW: a holistic approach to women's equality and freedom' in this volume. See also S. Cusack, 'CEDAW as a legal framework for transnational discourses on gender stereotyping' in this volume; C. Nyamu Musembi, 'Pulling apart? Treatment of pluralism in CEDAW and the Maputo Protocol' in this volume; R. Cook and S. Cusack, Gender Stereotyping: Transnational Legal Perspectives (Philadelphia: University of Pennsylvania Press, 2011); R. Holtmaat and J. Naber, Women's Human Rights and Culture: From Deadlock to Dialogue (Antwerp: Intersentia, 2010). 
it', who is to be distinguished from the 'kind of woman who did not ask for it'. ${ }^{108}$ Engaging with this issue in a meaningful and measurable, or at least results-indicative way, will prove challenging for the Working Group.

Implementation is also an issue. Zimbabwe has one of the most progressive laws on violence against women, but it is worth noting that it was drafted at one of the most violent times in the country's post-independence history ${ }^{109}$ There seems to be a disconnect between outlawing private violence while the state both condones and perpetuates public violence. ${ }^{110}$ Intransigent judges may also pose a problem. This is exemplified by the gratuitously offensive comments made by Kenyan judges in a case challenging the non-implementation of a provision in the 2010 constitution, which called for the appointment of Supreme Court justices to reflect a sex balance of one-third women and a maximum of two-thirds men. ${ }^{111}$

Compliance will be a problem for the Working Group. It is very much based on state cooperation. While it has been suggested that states that are compliant tend to have good laws and policies already, even those states can be stubborn and resistant. If an issue is controversial at the local level, governments may choose, for political gain, to defy the legal obligation to end discrimination, preferring the political gains to be had at the national level from open defiance. A recent example is the intransigence of Poland over abortion rulings made by the European Court of Human Rights in the Tysiac v. Poland case, which led to the State Party being requested by the CEDAW Committee to fulfil its obligations to women in this regard. ${ }^{112}$ The fact that Poland is yet to comply hints at the limits of law anticipated by Allott. ${ }^{113}$ Another example of a deliberate rolling back of gains made is the cynical passage of the 2009 Shia Personal Status law in Afghanistan by the Karzai Government, which

108 Amnesty International, Case Closed: Rape and Human Rights in the Nordic Countries: Summary Report (London: Amnesty International, 8 March 2010); CEDAW Committee, Concluding Observations: Norway, para. 23; Amnesty International, Breaking the Silence: Sexual Violence in Cambodia (London: Amnesty International, 8 March 2010).

109 A. Hellum et al., 'Rights claiming and rights making in Zimbabwe: a study of three human rights NGOs', in B. A. Andreassen and G. Crawford (eds.), Human Rights, Power and Non-Governmental Action: Comparative Analyses of Rights-Based Approaches and Civic Struggles in Development Contexts (London: Routledge, 2012).

110 F. Banda, 'Recent developments in Zimbabwe', in B. Atkins (ed.), International Survey of Family Law (London: Jordans, 2007) 333-51.

111 FIDA and Five Others v. Attorney General and Another [2011] Eklr (Petition 102 of 2011).

112 Tysiac v. Poland, ECHR Application no. 5410/03, 20 March 2007. See also L.C. v. Peru, UN Doc. CEDAW/C/50/D/22/2009 (4 November 2011).

113 A. Allott, The Limits of Law (London: Butterworth, 1980). 
was afraid of losing power in the election that was pending. Neither the complaints of local women's NGOs pointing out the discriminatory effects of the legislation on Shia women, nor the blandishments of the US-dominated coalition would convince the government to alter its position. Here the human rights of Shia women were sacrificed at the altar of political expedience.

A major problem facing the Working Group is that there may be differences in both understanding and interpretation of the idea of equality, not least within the regional human rights frameworks. The Protocol to the African Charter on the Rights of Women 2003 starts with the CEDAW-based definition of non-discrimination in Article 1, but rapidly changes, in the provisions on the division of property on divorce and death, to the more problematic entitlement to an 'equitable' rather than equal right to property. The effect is to create a lack of clarity. ${ }^{114}$ Equity, if understood as fairness, can yield a range of results from equal to unfair. Moreover, the choice of the word equitable in the property division sections reflects the reservations made by some states, not least Egypt, to Article 16 of the CEDAW, which cites as its justification for differential treatment of men and women in divorce:

Islamic Sharia's provisions whereby women are accorded rights equivalent to those of their spouses so as to ensure a just balance between them. This is out of respect for the sacrosanct nature of the firm religious beliefs which govern marital relations in Egypt and which may not be called in question and in view of the fact that one of the most important bases of these relations is an equivalency of rights and duties so as to ensure complementary which guarantees true equality between the spouses. ${ }^{115}$

The inconsistency between international and regional considerations on equality can also be found in the Revised Arab Charter 2004. Like its African counterpart, the Arab Charter appears to embrace, in Articles 11 and 3(1), the standard equal protection before the law and non-discrimination provisions found in the international system. However, it also invokes a model of equality grounded within a religious framework in Article 3(3), which provides:

114 See also the chapter by Nyamu Musembi in this volume.

115 Reservation of the Arab Republic of Egypt in respect of Article 16 of the CEDAW, available at: www.un.org/womenwatch/daw/cedaw/reservations-country.htm (last accessed 23 June 2012); see CEDAW General Recommendation No. 21 on Marriage and Family Relations, paras. 26, 34, 35. 
Men and women are equal in respect of human dignity, rights and obligations within the framework of the positive discrimination established in favour of women by the Islamic Shariah, other divine laws and by applicable laws and legal instruments. Accordingly, each State party pledges to take all the requisite measures to guarantee equal opportunities and effective equality between men and women in the enjoyment of all the rights set out in this Charter. ${ }^{116}$

Other points of difference between the regional and international include provisions on polygyny. The Human Rights and CEDAW Committees have both said that polygyny constitutes discrimination against women and is a breach of the principle of non-discrimination on grounds of sex. ${ }^{117}$ However, the African Protocol allows polygyny as a means of protecting women in existing (de facto) polygynous marriages. Moreover, in Hassam v. Jacobs N.O. the South African High Court preferred the African Protocol interpretation over that of the CEDAW, reasoning that denying widows of polygynous Muslim marriages from inheriting property and receiving maintenance under statutory law 'would be unfairly discriminatory against them and in be in conflict with the provisions of section 9 (non-discrimination) of the Constitution'. ${ }^{118}$ Which of these two interpretations will the Working Group choose: the strict reading of polygyny as discrimination, or the more nuanced one that perceives the banning of polygyny as being contrary to the interests of women who may be cast aside without access to property or maintenance?

Related to this is the changing understanding of discrimination over the decades. ${ }^{119}$ In the Banda Report some respondents cited labour laws based on old International Labour Organization Conventions proscribing

116 The interpretive provision, Article 43, is unhelpful in that it invokes both domestic and international law as guides to interpretation without specifying what is to happen in the event of a conflict between the 'protective' provisions of domestic law and the requirements of international human rights law. Other provisions making the rights subject to national law have the problem of breaching Article 27 of the Vienna Convention on the Law on Treaties, which provides that the national law cannot trump international provisions; but what of regional ones? See also CEDAW Committee, Concluding Observations: Saudi Arabia, paras. 13 and 14.

117 CEDAW General Recommendation No. 21, para. 14, Human Rights Committee, General Comment 28, Equality of rights between men and women (article 3), UN Doc. CCPR/C/21/Rev.1/Add.10 (2000), para. 24.

118 Hassam v. Jacobs N.O. and Ors Case No. 5704/2004, High Court (CPD), Judgment 18 July 2008, para. 19. See also para. 22. See also Ngwenyama v. Mayelane and Minister of Home Affairs (474/2011) [2012] ZASCA 94.

119 N. Hevener, 'An analysis of gender based treaty law: contemporary developments in historical perspective', Human Rights Quarterly 8:1 (1986) 70-88. 
women from working in the mines or the military as protective and thus positive, while others construed these as discriminatory. ${ }^{120}$

If the Working Group is to consider intersectional discrimination, then what is it to do about both legal and factual discrimination against minorities ${ }^{121}$ who are considered controversial in some regions? This could include the impact on lesbian women of laws that prohibit them from adopting children, or which deny or put additional barriers to them accessing reproductive technologies that are given to heterosexual women as of right. ${ }^{122}$ Increasingly, family provisions on the right to marry are drafted specifying that the marriage is between people of the opposite sex, rather than the more neutral drafting found in the International Bill of Rights. ${ }^{123}$ Should the Working Group engage with this issue given existing sensitivities? The experience of the Special Rapporteur on the promotion of rights while countering terrorism is telling. His report on terrorism and gender, which included a wide definition of gender identity and sexual orientation, was heavily criticized by states who said he had strayed from his remit. This points, some might argue, to a need for caution. ${ }^{124}$ Would intervening in issues pertaining to sexual orientation discrimination lead, as some have claimed, to a discrediting of the entirety of the Working Group's human rights work? Put simply - should lesbian women 'be sacrificed for the greater good'? Can a Working Group on laws that discriminate based on a human rights mandate take such an approach? What about non-discrimination being a binding norm of immediate enforceability without exception? The clear answer is a resounding 'No!'

${ }^{120}$ Banda Report at 109-11.

121 The mandate of the Working Group includes a consideration of minorities - HRC, Elimination of Discrimination, para. 17.

122 See generally $D u$ Toit and Another v. Minister of Welfare and Population Development and Others [2003] SA 198 (CC) on adoption; J and B v. Director General, Department of Home Affairs and Others [2003] (5) BCLR 463 (CC) on parental rights for a child conceived artificially; $V$.v. $V$ [1998] (4) SA 169 (HC) on custody.

123 Seefor example Revised Arab Charter, 2004 Article 33(1) and Constitution of the Republic of Kenya, 2010 Article 45(2). Cf Article 16(1) UDHR, Article 23(2) ICCPR, Article 10(1) ICESCR on the right to marry and found a family. While arguably the drafters anticipated marriage as being between two people of the opposite sex, it is possible to argue that, not having specified that marriage must be between men and women, leaves open the development of national laws to incorporate marriage between people of the same sex. This reading might be buttressed by factoring in developments in discrimination law that now incorporates sexual orientation as a protected ground. CESCR General Comment 20 on Non-discrimination, para. 34, CEDAW General Recommendation 28, para. 18.

124 Report of the Special Rapporteur on the Promotion and Protection of Human Rights and Fundamental Freedoms while Countering Terrorism, 3 August 2009, A/64/211, para. 20. 
If, as proclaimed in Vienna, 'human rights are women's rights', then there can be no equivocation on the part of the Working Group in tackling the often hate-filled and violent campaigns against lesbian women. ${ }^{125}$ Strengthening and buttressing the Working Group in its work should be the jurisprudence of human rights committees, which point to sexual orientation as a protected category. ${ }^{126}$ Furthermore, in 2011 the Human Rights Council itself adopted a Resolution on sexual orientation. ${ }^{127}$ Finally, it is worth noting that there has been enormous progress made at the national level, not least the Indian decision in the Naz Foundation case that led to the repeal of a section of the Penal Code that criminalized sexual activity between two people of the same sex. ${ }^{128}$ The Court highlighted that the ban had been based on British colonial laws and did not reflect Indian traditions and values, thus laying to rest the 'western imposition of perversion' theories that often dominate discussions on sexual orientation in Africa and beyond. ${ }^{129}$ The Indian example could be used by the Working Group as an example of good practice in its engagement with other states. Moreover, the Working Group could use positive examples from within a region in its engagement with recalcitrant states. ${ }^{130}$

In practice, the issue for the Working Group will be how to engage states with difficulties in a way that is not seen as antagonistic and judgemental.

125 See for example CEDAW Committee, Concluding Observations: Russian Federation, 16 August 2010, UN Doc. CEDAW/C/USR/CO/7, paras. 40 and 41. CEDAW Committee, Concluding Observations: Uganda, para. 44.

${ }^{126}$ M. O'Flaherty and J. Fisher, 'Sexual orientation, gender identity and human rights law: contextualising the Yogyakarta Principles', Human Rights Law Review 8 (2008) 207-48.

127 Human Rights Council Resolution on Human Rights, Sexual Orientation and Gender Identity, 15 June 2011 A/HRC/17/L.9/Rev.1; Report of the United Nations High Commissioner for Human Rights, Discriminatory laws and practices and acts of violence against individuals based on their sexual orientation and gender identity, 17 November 2011, A//HRC/19/41.

${ }^{128}$ Naz Foundation v. Government of NCT of Delhi and Others WP(C) No.7455/2001. See also, Atala Riffo and daughters v. Chile, Judgment of 24 February 2012, Series C No. 239 (Inter-American Court of Human Rights) (Spanish only), English translation of official summary issued by the IACtHR available at: http://williamsinstitute.law.ucla.edu/ wp-content/uploads/Summary-AtalaDecision-English-Mar-2012.pdf (last accessed 4 May 2012).

Human Rights Watch, This Alien Legacy: The Origins of 'Sodomy' Laws in British Colonialism, 17 December 2008.

129 See generally S. Tamale (ed.), African Sexualities (Oxford: Pambazuka, 2011). See also M. Mutua, 'Sexual orientation and human rights' in Tamale, African Sexualities, 452-62.

${ }^{130}$ R. Murray and F. Viljoen, 'Towards non discrimination on the basis of sexual orientation: the normative basis and procedural possibilities before the African Commission on Human and Peoples' Rights and the African Union', Human Rights Quarterly 29 (2007) 86-111. 
This will be particularly important in light of that part of the mandate requesting states to give 'serious consideration to responding favourably to the requests of the working group to visit their countries to enable it to fulfil its mandate effectively'. ${ }^{131}$ The Banda Report highlighted the importance of visits of Special Rapporteurs, especially to NGOs working in the field. NGOs reported that the engagement with state officials had helped to open up avenues of communication, and that following the visit of the Special Rapporteur, the NGOs had been able to press home the advantage by advancing their agenda on law reform. ${ }^{132}$ This reinforces the need for states to:

Provide gender-sensitive human rights education and training to public officials, including, inter alia, police and military personnel, corrections officers, health and medical personnel, and social workers, including people who deal with migration and refugee issues, and teachers at all levels of the educational system, and make available such education and training also to the judiciary and members of parliament in order to enable them to better exercise their public responsibilities. ${ }^{133}$

It is noteworthy that in the Beijing Platform for Action the strategic objective that follows that on equality and the need to eliminate discriminatory laws is on legal literacy, with states being required to translate human rights instruments into indigenous languages to facilitate learning and usage. Moreover, states are also required to: '(c) Disseminate information on national legislation and its impact on women, including easily accessible guidelines on how to use a justice system to exercise one's rights' and also to make known information on the international human rights complaint mechanisms and ways of accessing them. ${ }^{134}$

131 HRC, Elimination of Discrimination, para. 19.

132 Banda Report at 54-5. See also HRC, Elimination of Discrimination, para. 20 inviting NGOs to 'cooperate fully with the working group in the fulfilment of its mandate'.

133 Beijing Declaration, para. 232(i).

${ }^{134}$ Ibid. Strategic Objective 1:3, paras. 233(a), (c), (e). See also Rights of Women, Women's Access to Justice: A Research Report (London: Rights of Women, 4 February 2011). Available at: www.rightsofwomen.org.uk/pdfs/Policy/ Womens_access_to_Justice-a_research_report.pdf (last accessed 8 June 2012). 